Proc. Estonian Acad. Sci. Biol. Ecol., 2006, 55, 3, 243-261

\title{
Ice conditions of a large shallow lake (Lake Peipsi) determined by observations, an ice model, and satellite images
}

\author{
Anu Reinart ${ }^{\mathrm{a}^{*}}$ and Ove Pärn ${ }^{\mathrm{b}}$ \\ ${ }^{\text {a }}$ Department of Atmospheric Physics, Tartu Observatory, 61602 Tõravere, Tartumaa, Estonia \\ b Marine Systems Institute, Tallinn Technical University, Akadeemia tee 21, 19086 Tallinn, Estonia; \\ ove@sea.ee
}

Received 23 December 2004, in revised form 8 November 2005

\begin{abstract}
Lake Peipsi is one of the largest lakes in Europe and is totally covered with ice almost every winter. We introduce a thermodynamic ice model built for the investigation of ice seasons on Lake Peipsi. Long-time data from the Estonian national hydro-meteorological network on the air temperatures, wind speed and direction, and ice thickness and duration were used to develop and test the model. We ran the model for severe, normal, and mild winter conditions. Ice cover monitoring is complemented with ice maps derived from MODIS 250-m resolution images.
\end{abstract}

Key words: Boreal lake, lake ice, thermodynamic modelling, MODIS.

\section{INTRODUCTION}

Lake Peipsi on the border of Estonia and Russia is the fourth largest lake in Europe by its surface area $\left(3555 \mathrm{~km}^{2}\right)$, after the lakes of Ladoga and Onega in Russia and Vänern in Sweden. It is of great importance for both Russia and Estonia as a resource of drinking water, but also from the point of view of fishery, recreation, and traffic. The lake is under heavy anthropogenic load, as only partly treated wastewaters from two towns in Estonia and Russia are discharged into the lake. Various aspects of this large freshwater reservoir have been investigated already for about 150 years by Estonian and Russian scientists (Sokolov, 1983; Nõges, 2001 and references therein) and there are currently many international projects involving this lake.

\footnotetext{
* Corresponding author, anu.reinart@aai.ee
} 
The present paper concentrates on the investigation of the ice period on Lake Peipsi. Because of its shallowness (mean depth $\sim 7 \mathrm{~m}$ ) the winter ice cover is of great importance for the lake's ecosystem. The thickness of ice affects the active water volume and the duration of the ice period affects the annual cycle of production in shallow lakes (Nõges \& Nõges, 1989; Järvet, 1999a). Information about ice properties and movement has to be accessible also for traffic control and border security. On the global scale, the lake ice parameters such as thickness, freeze-up and break-up dates, and ice cover duration are good indicators of regional climate change in high-latitude regions (Robertson et al., 1992). Because of the large surface area of Lake Peipsi, it is difficult to collect data with sufficient spatial and temporal coverage. Therefore, modelling and remote sensing are useful tools for monitoring such large lakes.

In this paper results of an energy-balance model describing the seasonal evolution of ice on Lake Peipsi are presented. Many previous investigations have established relationships between air temperature and ice evolution processes (Palecki \& Barry, 1986; Jevrejeva \& Leppäranta, 2002). More complex approaches to describe lake ice processes use thermodynamic models, including processes in the atmosphere, snow, ice, water, and sediments (Patterson \& Hamblin, 1988; Liston \& Hall, 1995) according to specific conditions (Arctic lakes, melting period, shallow water, etc.). Depending on applications and availability of input data, all these models require certain simplification for numerical solutions and case-specific variables and parameterizations.

The results of the Lake Peipsi model presented in this paper are validated against lake-ice observations during three different winter types: mild, normal, and severe. The thermal influence of the Baltic Sea is the main factor in the formation of local differences in climatological conditions in the continental part of Estonia. According to the Baltic Sea Ice database IDA (Haapala et al., 1996), the winter of $1987 / 88$ can be considered as normal and 1986/87 as severe in the Baltic Sea region. By the mean air temperature and ice cover duration, the winter of 2001/02 was relatively mild. As even the seasons on the Baltic Sea are not exactly the same as the seasons on Lake Peipsi (Keevallik et al., 2001), we used field data for the mentioned winters for validation purposes.

Up to now, the ice conditions on Lake Peipsi have mainly been monitored close to the shore, and only occasional aerial and in situ observations are available. We introduce general ice conditions in Lake Peipsi by long-time monitoring (years 1949-2002) of ice break-up dates and measurements of ice thickness in one point.

Finally ice dynamics is described on the example of the winter of 2001/02 using MODIS 250-m resolution images. These show the ice movement over Lake Peipsi in such detail that has not been possible before, pointing out the need for the development of a complex dynamic-thermodynamic model. 


\section{MATERIAL}

Occurrence of ice phenomena as well as lake freeze-up and break-up dates are monitored in three points in Lake Peipsi, ice thickness has been measured $100 \mathrm{~m}$ from the coast at the stations of Mustvee and Praaga since 1921 and occasionally at Mehikoorma (shown in Fig. 1). Regular observations have been made since 1949 every fifth day.

Data needed to run the lake ice model were obtained also from Tiirikoja Meteorological Station close to Mustvee, which conducts a full meteorological survey: air temperature, water vapour content, water-equivalent precipitation, and wind speed and direction are registered every 3 hours. From these data daily average values are calculated for lake-ice model input.

To study the ice cover extent and ice motion images from the MODIS/Terra instrument were used. This sensor has high measurement frequencies and the satellite passes over our region so that Lake Peipsi is seen on 1 or 2 images each day. The images are freely available for scientific purposes through the data centre (http://daac.gsfc.nasa.gov/data/). MODIS/Terra provides a product for the snow and lake ice cover at 500-m resolution. To obtain more detailed information about ice conditions on Lake Peipsi, we used the MODIS product MOD02QKM, as this is of the finest spatial resolution $(250 \mathrm{~m})$. This product contains the MODIS Level-1B Calibrated, geolocated reflected radiances at two bands centred at $659 \mathrm{~nm}$
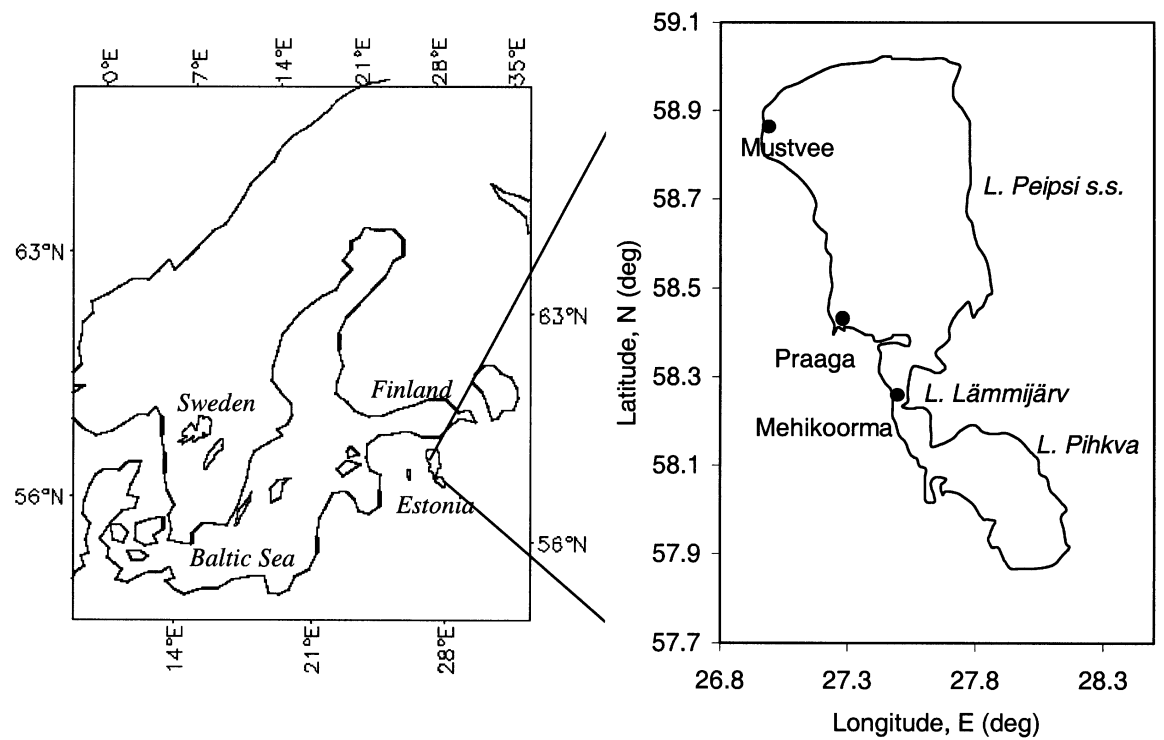

Fig. 1. Location map of Lake Peipsi in Europe. Morphological subdivisions of lake and ice observation stations of the Estonian Meteorological and Hydrological Institute are indicated. 
and $850 \mathrm{~nm}$ (bandbass 50 and $35 \mathrm{~nm}$ ), and a respective latitude and longitude for each 5 pixels. The software package ENVI 4.0 (Research Systems Inc.) was used for image processing and georeferensing.

\section{ICE CONDITIONS ON LAKE PEIPSI}

The first occurrence of ice is regarded as the beginning of early winter. The lake starts to freeze from the coast towards the centre. On Lake Peipsi this happens on average on 18 November and the ice cover lasts 28 days (Järvet, 1999b). When ice is monitored from the shore, the phrase "ice covered" means that the ice cover reaches the horizon; on average (years 1921-2002), this happens on 9 December (Table 1). However, there may be open water farther off the shore. Lake Peipsi has three parts (L. Peipsi sensu stricto, L. Lämmijärv, and L. Pihkva, Fig. 1). Freezing begins in lakes Lämmijärv and Pihkva about 1-7 days earlier and they become ice covered more quickly - about 1-2 weeks before Lake Peipsi s.s. (Järvet, 2001). Ice starts to break up on average on 4 April, and usually by 26 April the lake is ice free again (Table 1).

Lake Peipsi s.s. accumulates the largest amount of heat and therefore cools down later, freezes later, and opens later than smaller and shallower lakes Lämmijärv and Pihkva. The same is also true when comparing Lake Peipsi with another large Estonian lake, Võrtsjärv, where the ice cover lasts on average 18 days longer (Järvet, 1999a). There is a large temporal variability of ice phenomena characteristics of Lake Peipsi (Tables 1 and 2). Table 1 shows that dates indicating longer ice periods, earlier ice formation, and later melting refer to the 1920 s while warmer periods occurred in the 1990s. There is a statistically significant trend $(p<0.01)$ indicating that ice break-up has shifted in lakes Peipsi and Võrtsjärv about a month earlier during 50 years (Järvet, 1999b).

The ice thickness typically increases until late February-early March (Table 2), being on average $48 \pm 25 \mathrm{~cm}$. In normal winters ice is $50-60 \mathrm{~cm}$ thick and in a

Table 1. Description of ice cover duration in 1921-2002 as observed in the Mustvee Hydrological Station

\begin{tabular}{l|c|c|c|c}
\hline & $\begin{array}{c}\text { Ice cover } \\
\text { duration } \\
\text { (days) }\end{array}$ & $\begin{array}{c}\text { Date of } \\
\text { freeze-up }\end{array}$ & $\begin{array}{c}\text { Date of } \\
\text { break-up }\end{array}$ & $\begin{array}{c}\text { Date of last } \\
\text { ice phenomena }\end{array}$ \\
\hline Average & 115 & 9 Dec & 4 April & 26 April \\
Minimum or earliest date & $22(1993)$ & 11 Nov (1942) & 23 Dec (1993) & 25 Feb (1990) \\
Maximum or latest date & $164(1928)$ & 2 Feb (1991) & 3 May (1929) & 27 May (1926) \\
Winter 1986/87 (severe) & 120 & 15 Dec & 14 April & 6 May \\
Winter 1987/88 (normal) & 116 & 12 Dec & 9 April & 15 April \\
Winter 2001/02 (mild) & 87 & 24 Nov & 19 Feb & 18 April
\end{tabular}


Table 2. Seasonal variation of ice thickness (in $\mathrm{cm}$ ) on Lake Peipsi, measured at $100 \mathrm{~m}$ off the northern coast of the lake, at the Mustvee Hydrological Station in 1949-2002 (the year shown in the parenthesis)

\begin{tabular}{l|c|c|c|c|c|c}
\hline & Nov & Dec & Jan & Feb & March & April \\
\hline Average (1949-2002) \pm SD & $2 \pm 6$ & $13 \pm 14$ & $30 \pm 16$ & $48 \pm 18$ & $48 \pm 25$ & $18 \pm 29$ \\
Maximum (1949-2002) & 48 & 55 & 63 & 74 & 84 & 84 \\
& $(1993)$ & $(1989)$ & $(1960)$ & $(1954)$ & $(1954)$ & $(1960)$ \\
Number of years without ice & 42 & 10 & 3 & 3 & 4 & 20 \\
& & & $(1983$, & $(1989$, & $(1990$, & \\
& & & 1992, & 1992, & 1992, & \\
Min/max in 1986/87 & $0-5$ & $5-27$ & $27-53$ & $47-60$ & $63-68$ & $0-68$ \\
Min/max in 1987/88 & 0 & $21-26$ & $26-54$ & $55-65$ & $65-82$ & $0-71$ \\
Min/Max in 2001/2002 & $0-13$ & $16-38$ & $43-47$ & $43-45$ & $0-41$ & 0
\end{tabular}

harsh winter may be over $80 \mathrm{~cm}$ still in April. This temporal behaviour is similar to Lake Võrtsjärv (Järvet, 1999a), where the average ice thickness at the end of March is also $48 \mathrm{~cm}$. The thickest ice ever in Lake Peipsi $-120 \mathrm{~cm}$ - was measured at the centre of the lake in April 1965.

The freezing front moves from east to west over Estonia within three weeks. Lake Peipsi starts to freeze on 24 November, which is somewhat earlier than the coastal areas of the Gulf of Riga because the ice evolution processes in the sea are more connected with dynamic factors (strong winds, sea-level fluctuations, currents). The western part of Estonia lies under the direct influence of the sea while in the central and eastern parts the climate becomes gradually more continental and therefore seasons on the Baltic Sea do not correspond directly to seasons on Lake Peipsi. Statistical analysis of the Baltic Sea ice time series shows that the date of fast ice break-up (on average 6-12 April in the Gulf of Finland) is very close to the dates in Lake Peipsi (Table 2), and a statistically significant trend towards earlier ice break-up is found also in the Gulf of Riga ice stations (Jevrejeva \& Leppäranta, 2002).

\section{THERMODYNAMIC ICE MODEL}

A simple numerical model was developed that enables the simulation of the ice period in Lake Peipsi s.s. by calculating the evolution of the mean water temperature and ice thickness. The model is forced by surface energy balance based on 3-h values of the air temperature, precipitation, and wind speed from measurements in the Tiirikoja Meteorological Station. The lake and ice model describes the evolution of the lake water temperature together with the growth and melting of ice. 


\section{Surface energy balance}

Thermodynamic processes in the lake are driven by the heat fluxes at the interface of air and water/ice as schematically shown in Fig. 2. The energy balance equation is:

$$
Q_{\mathrm{T}}=Q_{\mathrm{SW}}(1-\alpha)+Q_{\mathrm{LW} \downarrow}+Q_{\mathrm{LW} \uparrow}+Q_{\mathrm{S}}+Q_{\mathrm{L}}+Q_{\mathrm{C}},
$$

where $Q_{\mathrm{T}}$ is the total energy flux available for the heating/cooling of water and melting/freezing of ice; all in $\mathrm{W} \mathrm{m}^{-2} ; Q_{\mathrm{SW}}$ is the solar radiation reaching the lake surface, $\alpha$ is the albedo of the surface, $Q_{\mathrm{LW} \downarrow}$ denotes the incoming longwave radiation and $Q_{\mathrm{LW} \uparrow}$ the emitted longwave radiation; $Q_{\mathrm{S}}$ is the turbulent exchange of sensible heat, $Q_{\mathrm{L}}$ is the turbulent exchange of latent heat, and $Q_{\mathrm{C}}$ is the energy transport in the ice due to heat conduction (absent during the ice-free period).

The solar radiation is calculated from the solar zenith angle $\theta$, fractional cloud cover $C a$, and atmospheric vapour pressure $P_{\mathrm{a}}$ according to (Shine, 1984):

$$
\begin{gathered}
Q_{\mathrm{SW}}=S T_{r} \cos \theta C l, \\
C l=1+0.0019(90-\theta)-0.62 C a, \\
T_{r}=\cos \theta\left[1.2 \cos \theta+(1+\cos \theta) P_{\mathrm{a}}+0.0455\right]^{-1},
\end{gathered}
$$

where $S$ is the solar constant. If the fractional cloud cover $C a<0.25$, its value is set to 0 .

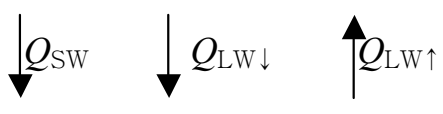

atmosphere

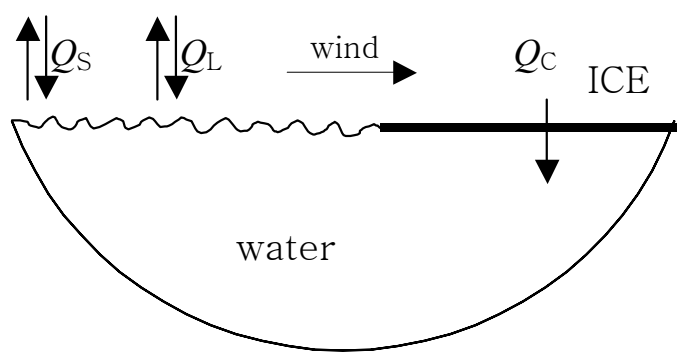

Fig. 2. Scheme of the components of an energy-balance lake ice model. 
Sensible and latent heat fluxes are calculated following Large \& Pond (1982):

$$
\begin{gathered}
Q_{\mathrm{S}}=\rho_{\mathrm{a}} C_{\mathrm{S}} c_{\mathrm{pa}} U_{\mathrm{a}}\left(T_{\mathrm{a}}-T_{\mathrm{v}}\right), \\
Q_{\mathrm{L}}=L \rho_{\mathrm{a}} C_{\mathrm{L}} U_{\mathrm{a}}\left(q_{\mathrm{a}}-q_{\mathrm{v}}\right),
\end{gathered}
$$

where $\rho_{\mathrm{a}}$ is the density of the air; $c_{\mathrm{pa}}$ is the specific heat of the air; $T_{\mathrm{v}}$ and $T_{\mathrm{a}}$ are the temperatures of water or ice/snow surface and air; $L$ is the latent heat of evaporation; $q_{\mathrm{a}}$ and $q_{\mathrm{v}}$ are specific humidity of the air and water or ice/snow surface; $U_{\mathrm{a}}$ is the wind speed; $C_{\mathrm{S}}$ and $C_{\mathrm{L}}$ are the turbulent exchange coefficients for sensible and latent heat, which depend on the atmospheric stability (values in Table 3) (Meier et al., 1999).

The net longwave radiation from the atmosphere and water/ice surface is calculated from the model for the Baltic Sea region by Zapadka et al. (2001):

$Q_{\mathrm{LW} \downarrow}+Q_{\mathrm{LW} \uparrow}=\sigma T_{\mathrm{a}}^{4}\left(0.732\left(1-\exp \left(-0.476 P_{\mathrm{a}}\right)\right)\right)\left(1-0.067 C a+0.301 C a^{2}\right)-\varepsilon \sigma T_{\mathrm{v}}^{4}$,

where $\sigma$ is the Stefan-Boltzman constant and $\varepsilon=0.97$ is the emissivity of the water surface.

Ice heat flux $Q_{\mathrm{C}}$ will be calculated when there is ice on the water surface.

When coupled to the lake and ice model described in the next sub-chapter, the energy balance described above gives boundary conditions for the surface temperature of water or the ice and snow layer.

\section{Lake and ice model}

During the ice-free period the mean temperature of the lake water is calculated by the heat conservation equation:

$$
\frac{\mathrm{d} T_{\mathrm{w}}}{\mathrm{d} t}=\frac{1}{\rho_{\mathrm{w}} c_{\mathrm{w}} h} Q_{T} \quad \text { when } \quad T_{\mathrm{w}}>0
$$

where $T_{\mathrm{w}}$ is the mean temperature, $\rho_{\mathrm{w}}$ is the density and $c_{\mathrm{w}}$ the specific heat of the water. Calculations are made with the effective water depth $h=1.2 \mathrm{~m}$, which gives the best approximation to the observed near-coastal lake water temperature during the ice-free period, incorporating also the effects of the coastal-offshore water exchange. The surface water temperature is taken equal to the mean water temperature: $T_{\mathrm{v}}=T_{\mathrm{w}}$. These simplifications are justified for Lake Peipsi, as the temperature stratification in the shallow lake is unsteady and already moderate winds above $5 \mathrm{~m} / \mathrm{s}$ mix the water column down to the bottom (Jaani, 2001). The few measurements of vertical temperature profiles, taken right before or after the formation of ice, show that by the end of the autumn cooling period the waters from top to bottom have almost entirely cooled to $\sim 0^{\circ} \mathrm{C}$. As an example, from 
2 to 17 December 2003 the water cooled from $1.7^{\circ} \mathrm{C}$ down to $0.2^{\circ} \mathrm{C}$ and no vertical stratification was evident.

Ice formation starts when the water temperature $T_{\mathrm{w}}$ falls below the freezing temperature $T_{\mathrm{f}}, T_{\mathrm{w}}<T_{\mathrm{f}}$. Further heat loss of the water column is converted to the increase of the ice thickness $H_{\mathrm{i}}$. When ice is present then at negative air temperatures precipitation $P$ forms a snow layer with a thickness of $H_{\mathrm{s}}$ on top of the ice cover:

$$
\frac{\mathrm{d} H_{\mathrm{s}}}{\mathrm{d} t}=\frac{\rho_{\mathrm{w}}}{\rho_{\mathrm{s}}} P
$$

where $\rho_{\mathrm{s}}$ and $\rho_{\mathrm{w}}$ are snow and water density, respectively (Table 3).

The thermodynamic growth of thin ice (up to $5 \mathrm{~cm}$ ) and melting of ice or snow take place at the ice/snow surface and are controlled by the heat flux:

$$
\begin{gathered}
L_{\mathrm{i}} \rho_{\mathrm{i}} \frac{\mathrm{d} H_{\mathrm{i}}}{\mathrm{d} t}=-\left(Q_{\mathrm{T}}-Q_{\mathrm{I}}\right) \text { when } H_{\mathrm{s}}=0 \text { and } H_{\mathrm{i}}>0 \\
L_{\mathrm{s}} \rho_{\mathrm{s}} \frac{\mathrm{d} H_{\mathrm{s}}}{\mathrm{d} t}=-Q_{\mathrm{T}} \text { when } H_{\mathrm{s}}>0 \text { and } H_{\mathrm{i}}>0 \text { and } Q_{\mathrm{T}}>0 \text { (melting), }
\end{gathered}
$$

where $Q_{\mathrm{I}}=Q_{\mathrm{SW}}(1-\alpha) \exp \left(-k_{\mathrm{z}} H_{\mathrm{i}}\right)$ is the shortwave radiation reaching the depth $H_{\mathrm{i}}, k_{\mathrm{z}}=1.5 \mathrm{~m}^{-1}$ is the light attenuation coefficient in ice, $L_{\mathrm{i}}$ and $L_{\mathrm{s}}$ are the latent heat of freezing, and $\rho_{\mathrm{i}}$ and $\rho_{\mathrm{s}}$ are the density of ice and snow, respectively. Based on the definitions of $Q_{\mathrm{T}}$ and $Q_{\mathrm{I}}$, in (7) the shortwave radiation absorbed

\begin{tabular}{|c|c|c|}
\hline Symbol & Parameter & Value \\
\hline$k_{\mathrm{i}}$ & Thermal conductivity of ice & $2.1 \mathrm{~W} \mathrm{~m}^{-1} \mathrm{~K}^{-1}$ \\
\hline$k_{\mathrm{s}}$ & Thermal conductivity of snow & $0.3 \mathrm{~W} \mathrm{~m}^{-1} \mathrm{~K}^{-1}$ \\
\hline$C_{\mathrm{S}}$ & $\begin{array}{c}\text { Turbulent exchange coefficient of } \\
\text { sensible heat } T_{\mathrm{a}}<T_{\mathrm{i}} \\
T_{\mathrm{a}}>T_{\mathrm{i}}\end{array}$ & $\begin{array}{l}1.15 \times 10^{-3} \\
0.6 \times 10^{-3}\end{array}$ \\
\hline$C_{\mathrm{L}}$ & $\begin{array}{l}\text { Turbulent exchange coefficient } \\
\text { of latent heat }\end{array}$ & $1.15 \times 10^{-3}$ \\
\hline$c_{\mathrm{pa}}$ & Specific heat of air & $1.008 \times 10^{-3} \mathrm{~J} \mathrm{~kg}^{-1} \mathrm{~K}^{-1}$ \\
\hline$\rho_{\mathrm{s}}$ & Density of snow & $300 \mathrm{~kg} \mathrm{~m}^{-3}$ \\
\hline$\rho_{\mathrm{i}}$ & Density of ice & $915 \mathrm{~kg} \mathrm{~m}^{-3}$ \\
\hline$\rho_{\mathrm{w}}$ & Density of water & $1000 \mathrm{~kg} \mathrm{~m}^{-3}$ \\
\hline$L$ & Latent heat of evaporation & $2.5 \times 10^{-6} \mathrm{~J} \mathrm{~kg}^{-1}$ \\
\hline$L_{\mathrm{i}}$ & Latent heat of freezing & $3.33 \times 10^{-5} \mathrm{~J} \mathrm{~kg}^{-1}$ \\
\hline$\alpha$ & Snow/ice albedo & $0.15-0.8$ \\
\hline
\end{tabular}
in the ice is $Q_{\mathrm{R}}=Q_{\mathrm{SW}}(1-\alpha)\left[1-\exp \left(-k_{\mathrm{z}} H_{\mathrm{i}}\right)\right]$.

Table 3. Parameters used in the thermodynamic lake ice model 
The growth of thicker columnar ice depends on the heat flux $Q_{\mathrm{C}}$, which is conducted from the upper ice/snow surface towards the ice-water interface $\mathrm{z}=-H_{\mathrm{i}}$. Instead of (7) we obtain:

$$
L_{\mathrm{i}} \rho_{\mathrm{i}} \frac{\partial H_{\mathrm{i}}}{\partial t}=-\left.k_{\mathrm{i}} \frac{\partial T_{\mathrm{i}}}{\partial z}\right|_{\mathrm{z}=-H_{\mathrm{i}}}=Q_{\mathrm{C}}
$$

where $k_{\mathrm{i}}$ is thermal conductivity of the ice layer.

The zero-layer model by Semtner (1976) with linear temperature profiles in both the ice and the snow layer is used as an approximation for Lake Peipsi. This approximation for the Baltic Sea ice is also used by Haapala \& Leppäranta (1996).

Assuming steady heat fluxes in the ice and snow layers at each time step of the model, the conductive heat flux at the ice-water interface is calculated as:

$$
Q_{\mathrm{C}}=\frac{k_{\mathrm{i}} k_{\mathrm{s}}}{k_{\mathrm{i}} H_{\mathrm{s}}+k_{\mathrm{s}} H_{\mathrm{i}}}\left(T_{\mathrm{f}}-T_{\mathrm{v}}\right),
$$

where $k_{\mathrm{i}}$ and $k_{\mathrm{s}}$ are the thermal conductivity of the ice and snow, respectively (Table 1); $T_{\mathrm{f}}$ is the temperature at the ice-water interface, equal to freezing temperature. For fresh water, $T_{\mathrm{f}}=273 \mathrm{~K}$. Surface temperature at the ice/snow and air interface $T_{\mathrm{v}}$ is calculated from (9) as

$$
T_{\mathrm{v}}=T_{\mathrm{f}}+\frac{k_{\mathrm{s}} H_{\mathrm{i}}+k_{\mathrm{i}} H_{\mathrm{s}}}{k_{\mathrm{i}} k_{\mathrm{s}}} Q_{\mathrm{T}},
$$

where all the symbols are as described above and have numerical values shown in Table 3. Since the total surface heat flux $Q_{\mathrm{T}}$ depends on the surface temperature $T_{\mathrm{v}}$, Eq. 10 is solved iteratively for each model time step.

For albedo in Eq. 1, we used five different values according to different ice surface conditions: new snow -0.8 , bare ice -0.5 , melting ice -0.3 , melting ice when the air temperature is over $9 \mathrm{~h}$ higher than $2^{\circ} \mathrm{C}-0.15$, and water -0.05 . These values are estimated by field measurements on Estonian and Finnish lakes (Leppäranta et al., 2003).

The calculations were made using meteorological data since 01.06.1985 till 31.12.1989 and 01.01.2001-31.12.2002 with a 3-h time step.

\section{MODELLING RESULTS}

\section{Ice thickness}

The thermodynamic ice model was run with the daily meteorological data measured at the Tiirikoja station located approximately $5 \mathrm{~km}$ from the point of ice 
sampling, for mild (2001/02), severe (1986/87), and normal (1987/88) winters, whose ice conditions are characterized in Tables 1 and 2.

According to the air temperature measurements, December was the coldest $\left(-8.0^{\circ} \mathrm{C}\right)$ month in the winter of $2001 / 02$, but according to the long-time observations, the coldest month at Tiirikoja is February $\left(-7.1^{\circ} \mathrm{C}\right)$ (Keevallik et al., 2001). So that winter was cold during the time of ice formation, but stayed relatively warm for the rest of the winter (the average temperature in February 2002 was $0^{\circ} \mathrm{C}$ ) (Fig. 3a). During the severe winter of 1986/87 the air temperature stayed much lower (Fig. 3a), and the wind was generally weaker than during the mild winter (Fig. 3b). The amounts of precipitation were rather similar in both years (Fig. 3c).

Comparison of the calculated ice thicknesses with the observed data at different stations over the lake during the ice-cover period in different winters is presented in Fig. 4. The same relative differences in the ice thickness between the years are seen also from the modelled data, and the general patterns of the measured ice growth are captured by the model. The model produces the greatest ice thickness $-68 \mathrm{~cm}$ at the end of March - for the severe winter of 1986/87. In the normal winter of 1987/88 the maximum ice thickness according to the model was $64 \mathrm{~cm}$, which was also at the end of March. For the warm winter of 2001/02 the model produces $46 \mathrm{~cm}$ at the end of January as maximum. According to the observations, the ice was the thickest $(82 \mathrm{~cm})$ in the normal winter, followed by the severe winter (68 $\mathrm{cm}$ at the Mustvee station). The ice-cover period was longer in the severe winter than in the normal winter (Table 1). During the normal winter alternating warm and cold periods may have caused ice movement over the lake and layers of ice were placed on top of each other, so the measurements of ice thickness show large variation (Fig. 4b). The mild winter of 2001/02 is characterized by the shortest ice-cover period, even though it formed earlier than in the other years used for the tests, and the maximum ice thickness $(47 \mathrm{~cm})$ was registered in January. Southern parts of the lake were ice free already in the middle of February.

For the normal and severe winters the modelled values are between maximum and minimum observed values (Fig. 4a,b). In mild years, ice disappears from some stations and the model gives comparable results only with the northernmost Mustvee/Tiirikoja station where ice still exists. It is also possible that during mild winters local climatic conditions over the lake differ more than during colder years, and the model predicts better ice conditions close to meteorological measurements.

The simulations of the ice thickness evolution are good as the modelled vs. observed points lie close to the $1: 1$ line (Fig. 5); the correlation coefficients were $0.92-0.97$ for different years. For this comparison only the modelled results that correspond to the measurement dates at the Mustvee station were used. The model estimates ice thickness with a maximum error of $21 \%$ when ice covers the lake. For mild winters when large open-water areas affect the energy budget and ice moves easily, errors may be much larger. 

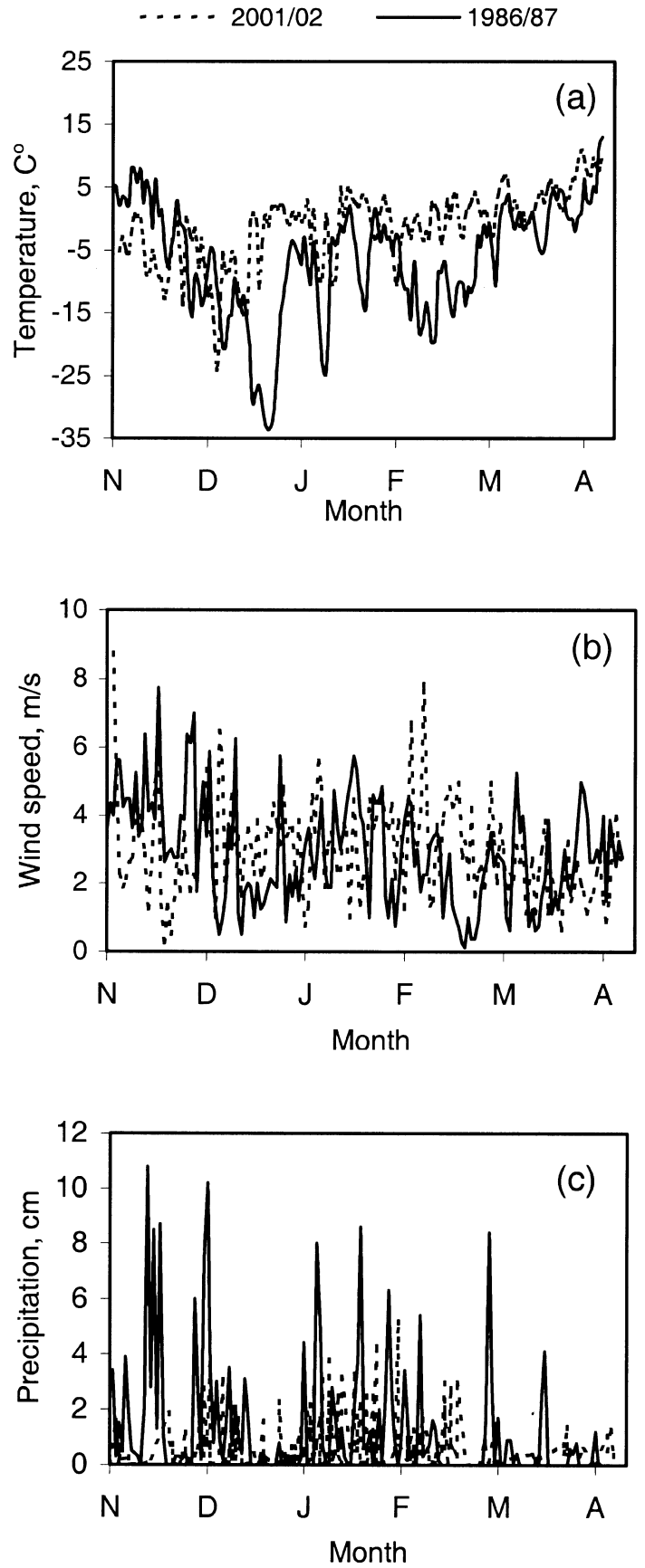

Fig. 3. Meteorological conditions in mild and severe winters by measurements at the Tiirikoja station: (a) average daily air temperature, (b) wind speed, and (c) precipitation. 

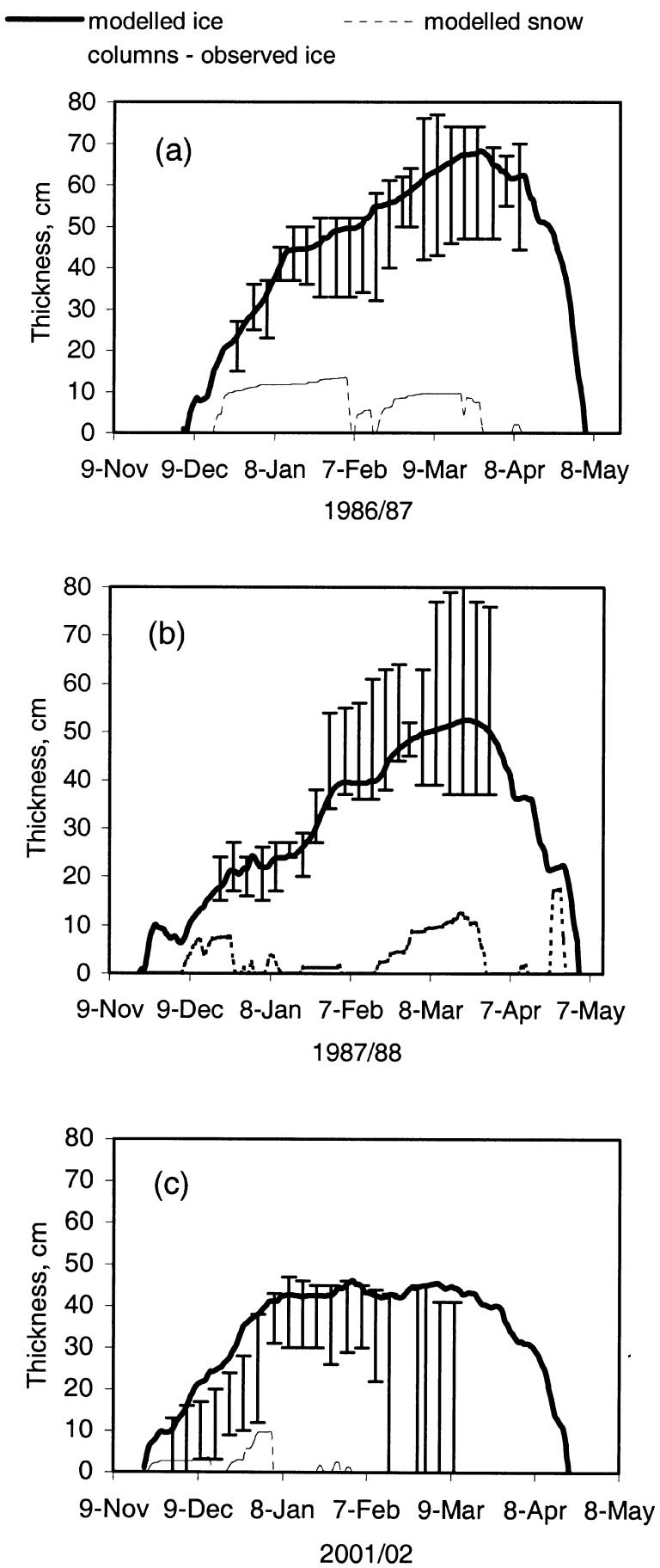

Fig. 4. Measured and modelled ice thickness and snow depth in the winters of (a) 1986/87, severe; (b) 1987/88, normal; and (c) 2001/2002, mild. 


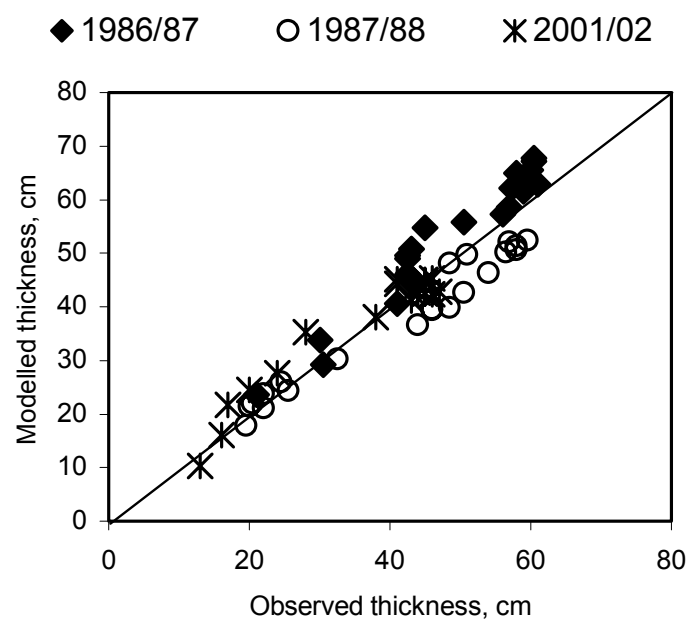

Fig. 5. Relationship between the modelled ice thickness and measured ice thickness for all three tested (severe, normal, and mild) winters.

The date of the last ice phenomena fixed by observations fitted surprisingly well with the modelled zero ice thickness for all tested years, the difference being only 2 days. Dates of the first ice phenomena are more rarely fixed in observation dairies (maybe due to poor observation conditions during the dark and windy period in late autumn), but these may occur 7 to 40 days later than the modelled ice-cover formation. Dates of the first/last ice phenomena cannot be predicted using only a thermodynamic model in such a large lake where dynamic factors (strong wind, river inflow, and currents) may have a much stronger effect during the transition periods in spring and autumn than during stable (especially average or cold) winter conditions.

\section{Error analysis}

One reason for errors in the model is patchiness of the snow cover and uncertainty of snow and snow-ice properties used in the model. In the model simulation, thin snow $(0-5 \mathrm{~cm})$ has a weak effect on the results. However, the winter of 1986/87 was rich in snow, and for simulations that did not include snow, the model produced up to $68 \%$ thicker ice and later melting than with snow. For ice growth in autumn the model gave the same results with and without snow. For the mild winter of 2001/02 the difference was up to $19 \%$ and there was no significant shift in the ice melt date. The effect of snow cover on ice thickness is also notable in Fig. 4b, where additional snow in spring 1988 slows down the decrease of ice thickness. 
We assumed that snow-ice formation in a large lake is limited. Then snow cover is rarely sufficient to depress the ice surface below water because of cold and windy conditions (Liston \& Hall, 1995).

However, the measured snow thickness is occasionally up to $50 \mathrm{~cm}$ (20 March 1988), which might be enough to form an opaque snow-ice layer on top of clear transparent lake ice. During warmer periods, the freezing of rain and the melting of snow may also form layers of snow-ice, as observed in many other lakes in Estonia (Leppäranta et al., 2003). This snow-ice is rich in air bubbles and its density is much less than that of clear ice formed by frozen lake water. During the melting period, snow-ice can accumulate heat and therefore ice melts slower than it could melt without snow and snow-ice.

Other factors causing errors in estimates of ice thickness are cloudiness and wind speed. They affect the radiation budget directly but also indirectly affecting snow and ice surface properties by melting and packaging snow. The short-wave radiation estimated by Eq. 2 depends on the fraction of cloudiness, which may largely differ over the open area of the lake and in coastal regions. The measured values of wind speed are rather low (mainly $2-4 \mathrm{~m} / \mathrm{s}$, Fig. 3b), which could mean that the measurement site is blocked from wind to some extent, and stronger winds actually blow over the lake. However, without direct measurements it is impossible to confirm this.

Not all discrepancies between modelled and observed values are errors. Especially for autumn and spring periods it is important to take into account also the dynamic processes of the ice on large lakes. During the ice melting and forming periods drift ice moves around on the lake, forming ridges and rafted ice.

\section{SPATIAL DYNAMICS OF ICE}

\section{Satellite image data}

Estimations of the ice albedo can be performed with optical sensors, such as the AVHRR, Landsat TM, ETM+, and MODIS (Riggs et al., 1999). Measurements of the lake ice show changes in the albedo of the ice over the seasons in the whole spectral range of 400-900 nm (Leppäranta et al., 2003). The albedo characteristics of snow-covered ice are similar to those of snow. As the snow melts on the ice, the albedo decreases across all wavelengths (Rasmus et al., 2002). The open water typically has a very low albedo for total radiance $(<7 \%)$, in contrast to the highlyreflective snow-covered ice $(80 \%)$.

A total of 16 cloud-free MODIS (http://modis-snow-ice.gsfc.nasa.gov) images were available for the ice period in 2002, starting from 1 February. Comparison of these images with meteorological data showed that the lake is usually seen from the space during high air pressure conditions when the weather is cold in winter. Unfortunately, no images were available for the ice-forming period in November and December because of cloudiness and low sun. 
By the reflectance at two MODIS bands (659 and $865 \mathrm{~nm}$ ) it is relatively easy to distinguish between the open water and ice cover and detect cracks, fractures, and openings in the ice sheet. The surface area of the lake ice was calculated from all images. On 1 February 2002 the ice surface was $100 \%$ of the total lake surface, but on 9 April 2002 only 5\%. The accuracy of the estimate slightly depends on the correct geolocation. When the lake happens to be on a remote area of the image, the shape of the pixels will be prolongated. On the 16 images the lake area varied within $10 \mathrm{~km}^{2}$, which is $0.3 \%$ of its actual area. Other factors affecting the results are the cloud cover and thin ice with low reflectance. The effect of the cloud cover is minimized by choosing only such images where ice can be seen through the cloud. Some types of ice, such as nilas and young ice, can be difficult to identify because they lack a sharp contrast with the open water. We suppose that the regions with low reflectance are small and insignificant compared with the whole ice cover.

\section{Ice movement over the lake in 2002}

On the earliest image of Lake Peipsi ice cover (1 February 2002) it can be seen that the lake is totally frozen and uniformly covered with ice (Fig. 6a). Due to the temperature fluctuations in winter the ice shrinks, and fractures from $10 \mathrm{~cm}$ to several metres may occur, but they cannot be seen on the images with $250-\mathrm{m}$ spatial resolution. The weather stays warm (daytime temperature above zero) from 2-14 February and cracks with a width of about $1 \mathrm{~km}$ appear into the ice sheet. Local fishermen say that large cracks have appeared every year at approximately the same place already for hundreds of years. Cracks usually proceed parallel to the shore in the places where the depth of the lake changes. Temperature differences between the shallow and deep parts of the lake may cause differences in ice thickness, and later such a region is more likely to break due to wind stress and currents.

The temperature is below zero from 22 February to 9 March when it turns warm again. On the image from 15 March (Fig. 6b) a large opening in the northern area of the lake can be seen. On the images the open water in the shallowest area, Lake Lämmijärv, where ice melts first, is clearly visible. During the next 6 days the wind turned from north-west to south-east and the opening in the northern part closed, ice broke over the whole ice sheet, and a new opening in the southern area appeared. At the end of March the wind turned to the west $(265-271 \mathrm{deg})$ and moved the ice sheet to the eastern side of the lake, towards Russia. During all that time the measured wind speed did not exceed $4.8 \mathrm{~m} / \mathrm{s}$. By the end of the month (Fig. 6c) about half of the lake was covered with ice. After that a relatively weak wind $(2-3 \mathrm{~m} / \mathrm{s})$ from the east pushed the ice over the whole lake within two days and pressed it onto the western coast of Lake Peipsi, where it stayed until it totally melted. Such ice ridges on the coast may be as high as $10 \mathrm{~m}$ and 


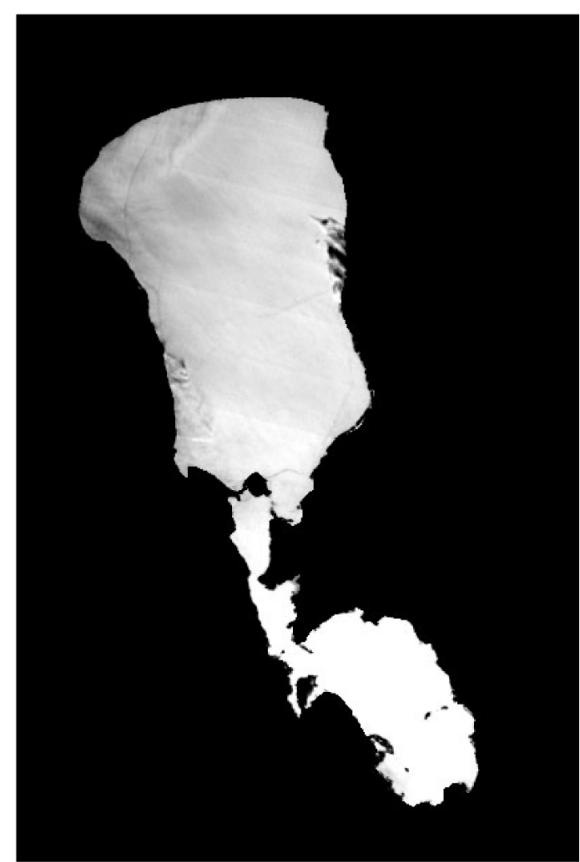

(a)

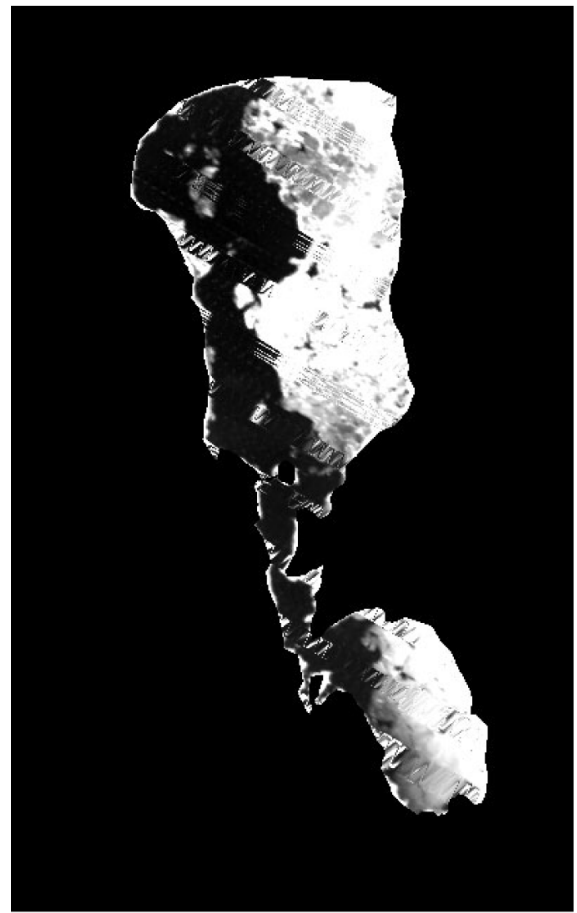

(c)

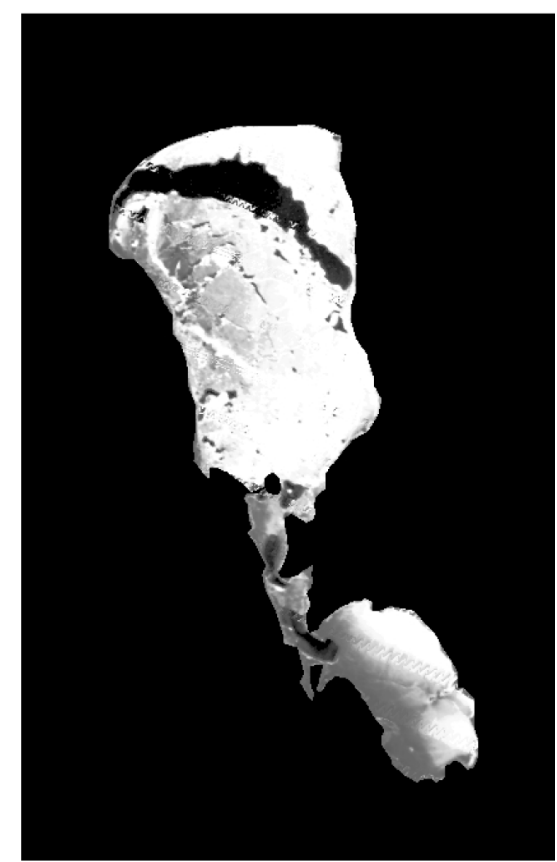

(b)

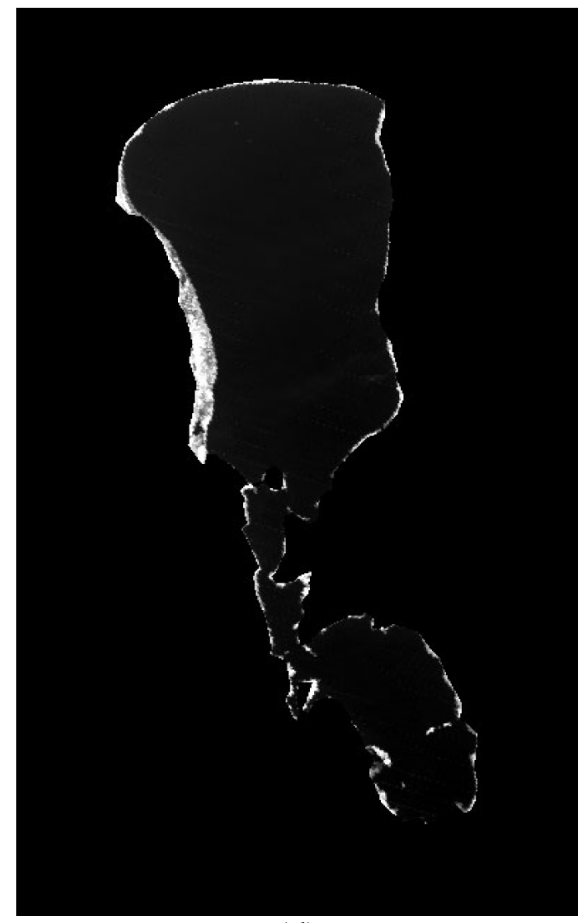

(d)

Fig. 6. Change of ice conditions on Lake Peipsi in 2002 according to the MODIS/Terra images: (a) 1 Feb 2002, (b) 15 March 2002, (c) 29 March 2002, and (d) 8 April 2002. 
destroy the coastal beach, trees, or even buildings in old times (Jaani, 2001). More commonly ice accumulates in the north-east side of the lake because of prevailing western winds (Keevallik et al., 2001).

We compared our ice maps with the MODIS 500-m resolution lake ice product, MOD10_L2. This product is a preliminary product for 19 lakes over the world, and Lake Peipsi is one of them. For a very clear day and with the satellite looking almost straight to the lake surface (same image as shown in Fig. 6b), the open water area is well recognized also by the standard product, but there is misclassification of ice, which starts to melt and has relatively low reflectance (looks gray in Fig. 6b). Field investigations confirm the low values of the lake ice albedo when the ice surface becomes wet; however, they also show large variability in the spectral shape and values according to impurities of ice (Leppäranta et al., 2003). Further direct measurements of optical properties of Lake Peipsi ice would be profitable not only for the ice model but also for satellite remote sensing of lake ice.

\section{CONCLUSIONS}

On average, the ice cover on Lake Peipsi s.s. lasts for 115 days, from 9 December to 4 April. In a severe winter, the ice may be about $80 \mathrm{~cm}$ thick even in April. The temporal behaviour of ice thickness is rather similar to that of the other large lake in Estonia, Võrtsjärv. They both show an earlier break-up of the ice cover similarly to many other lakes in the Northern Hemisphere, indicating an increase in the spring air temperature in this region.

The thermodynamic ice model developed for Lake Peipsi describes the ice thickness in Peipsi s.s. well, having a correlation coefficient higher than 0.94, and a standard error less than $21 \%$ for cold and normal winters. For mild winters, the model is only valid for ice conditions in the northern part of the lake. However, general patterns of the measured ice growth are captured by the model.

This model is especially useful for the melting period, when no field measurements are often available. The model can be used in studies of ecological conditions in the lake in the wintertime and for simulations related to global climate change. In such a large lake the ice movement affects ice data monitored close to the coast, as the ice is moved around on the lake already by a weak $(3-4 \mathrm{~m} / \mathrm{s})$ wind before it melts totally. The future plans include development of a dynamic model for this lake and coupling it to the present thermodynamic model.

Ice cover monitoring can be complemented with ice maps, ice break-up dates, and dynamic features during the melting period derived from MODIS 250-m resolution images. The MODIS standard product needs more evaluation and comparison with field measurements before applying it to Lake Peipsi as bare and wet lake ice may have much lower reflectance in the red and near infrared bands than assumed presently. 


\section{ACKNOWLEDGEMENTS}

This study was supported by the Estonian Science Foundation (grants Nos 5868 and 6814) and the EU project CLIME. We wish to thank the Estonian Meteorological and Hydrological Institute and the Tiirikoja Station for ice and meteorological data; and Goddard DAAC MODIS Data Support (Code 902) for the production and distribution of images.

\section{REFERENCES}

Haapala, J. \& Leppäranta, M. 1996. Simulating the Baltic Sea ice season with a coupled ice-ocean model. Tellus, 48, 622-643.

Haapala, J., Alenius, P., Dubra, J., Klyachin, S., Kõuts, T., Leppäranta, M., Omstedt, A., Pakstys, L., Scmelzer, N. \& Schrum, C. 1996. Ice data bank for Baltic Sea climate studies. Rep. Ser. Geophys., Rep. 35. Department of Geophysics, University of Helsinki.

Jaani, A. 2001. Thermal regime and ice condition. In Lake Peipsi. Meteorology, Hydrology, Hydrochemistry (Nõges, T., ed.), pp. 65-72. Sulemees Publishers, Tartu.

Järvet, A. 1999a. Influence of ice cover on the ecological conditions of shallow Lake Vortsjärv. Publ. Inst. Geogr. Univ. Tartu., 84, 92-100.

Järvet, A. 1999b. Climatological calendar of Estonian lakes and its long-term changes. Nordic Hydrol. Prog. Rep., 47 (Killingtveit, Å., ed.), 2, 677-687.

Järvet, A. 2001. Veekogude klimaatilised aastaajad. Publ. Inst. Geogr. Univ. Tartu., 90, 48-81.

Jevrejeva, S. \& Leppäranta, M. 2002. Ice conditions along Estonian coast in a statistical view. Nord. Hydrol., 33, 241-267.

Keevallik, S., Loitjärv, K., Rajasalu, R. \& Russak, V. 2001. Meteorological regime of Lake Peipsi. In Lake Peipsi. Meteorology, Hydrology, Hydrochemistry (Nõges, T., ed.), pp. 18-38. Sulemees Publishers, Tartu.

Large, W. G. \& Pond, S. 1982. Sensible and latent heat flux measurements over the ocean. J. Phys. Oceanogr., 12, 464-482.

Leppäranta, M., Reinart, A., Erm, A., Arst, H., Hussainov, M. \& Sipelgas, L. 2003. Investigation of ice and water properties and under-ice light fields in fresh and brackish water bodies. Nord. Hydrol., 34, 245-266.

Liston, G. E. \& Hall, D. K. 1995. An energy-balance model of lake-ice evolution. J. Glaciol., 41, 373-382.

Meier, M., Döscher, R. \& Coward, A. 1999. RCO - Rossby Centre regional Ocean climate model: model description and first results from the hindcast period 1992/93. SMHI Rep., 26.

Nõges, P. \& Nõges, T. 1989. The effect of fluctuating water level on the ecosystem of Lake Võrtsjärv, Central Estonia. Proc. Estonian Acad. Sci. Biol. Ecol., 47, 98-113.

Nõges, T. (ed.) 2001. Lake Peipsi. Meteorology, Hydrology, Hydrochemistry. Sulemees Publishers, Tartu.

Palecki, M. A. \& Barry, R. G. 1986. Freeze-up and break-up of lakes as an index of temperature changes during the transition seasons: a case study in Finland. J. Climate Appl. Meteor., 25, 93-902.

Patterson, J. C. \& Hamblin, P. F. 1988. Thermal simulation of a lake with winter ice cover. Limnol. Oceanogr., 33, 323-338.

Rasmus, K., Ehn, J., Granskog, M., Kärkäs, E., Leppäranta, M., Lindfors, A., Pelkonen, A., Rasmus, S. \& Reinart, A. 2002. Optical measurements of sea ice in the Gulf of Finland. Nord. Hydrol., 33, 207-226. 
Riggs, G. A., Hall, D. K. \& Ackerman, S. A. 1999. Sea ice extent and classification mapping with the Moderate Resolution Imaging Spectroradiometer Airborne Simulator. Rem. Sens. Env., 68, 152-168.

Robertson, D. M., Ragotzkie, R. A. \& Magnuson, J. J. 1992. Lake ice records used to detect historical and future climatic change. Clim. Change., 21, 407-427.

Semtner, A. J. 1976. A model for the thermodynamic growth of sea in numerical investigations of climate. J. Phys. Oceanogr., 6, 379-389.

Shine, K. P. 1984. Parametrization of shortwave flux over high albedo surfaces as a function of cloud thickness and surface albedo. Quart. J. R. Meteorol. Soc., 110, 747-764.

Sokolov, A. A. 1983. Chudsko-Pskovskoe ozero. Gidrometeoizdat, Leningrad.

Zapadka, Z., Wozniak, S. \& Wozniak, A. 2001. A simple formula for Baltic Sea surface net infrared radiation flux. Oceanologia, 43, 265-277.

\section{Peipsi järve jäätingimustest vaatluste, mudeli ja satelliidipiltide põhjal}

\section{Anu Reinart ja Ove Pärn}

Peipsi järv, üks suuremaid Euroopa järvi, on igal talvel peaaegu täielikult jäätunud. Artiklis on tutvustatud termodünaamilist jäämudelit, mis on koostatud Peipsi järve jääolude uurimiseks. Pikaajalised andmed õhutemperatuuri, jää paksuse, tuule suuna ning kiiruse jm kohta on mõõdetud Eesti hüdrometeoroloogia vaatlusvorrgus. Neid andmeid on kasutatud mudeli koostamisel. Mudelit on testitud kolme erineva talvetüübi jaoks: soe, keskmine ja karm talv. Tulemused on head keskmiste ja külmade talvede jaoks, kuid soojade talvede korral on oluline arvestada lisaks ka jää liikumist akvatooriumis. Jää liikumise jälgimiseks on täiendavalt kasutatud 250-meetrise lahutusega MODIS/Terra satelliidipilte. 